We cherish our fellow human beings and respect their aspirations, but realize that, if present trends continue, there could be far too many of us on Earth. Therefore a basic imperative must be to discourage excessive population growth. Another should be for our leaders to turn aside from sectarian or individual concerns, however pressing they may seem, at least sufficiently to make sure that their national administrations do not lose sight of everybody's dependence on The Biosphere as an integrated whole.

To such ends we pledge our faith in a robust future for the world provided The Biosphere is suitably fostered, and sign individually but with warm collective feeling from its six populated continents:

\author{
N. AMERICA: Linus Pauling (Palo Alto, California) \\ Nobel Prizes (unshared) \\ for Chemistry and for Peace \\ S. AMERICA: Felipe Benavides (Lima, Peru) \\ President of PRODENA; \\ International conservation \\ laureate \\ EUROPE: Friedrich T. Wahlen (Berne, Switzerland) \\ Formerly President of the Swiss \\ Confederation; sometime Deputy Director- \\ General of FAO
}

\author{
AFRICA: Mohamed Kassas (Giza, Egypt) \\ President of IUCN; \\ Professor of Botany in the University of Cairo \\ ASIA: B. B. Vohra (New Delhi, India) \\ Chairman of the Indian National \\ Committee on Environmental \\ Planning \\ AUSTRALASIA: George A. Knox (Christchurch, N.Z.) \\ President of INTECOL; \\ Professor of Zoology in the \\ University of Canterbury
}

\title{
EDITORIAL STATEMENT
}

\section{World Campaign for The Biosphere}

$\mathrm{T}$ The Biosphere is the 'envelope' or sphere surrounding the Earth in which life exists naturally. It ranges from the sediments at the bottom of deep-ocean 'trenches' up to the highest levels of the atmosphere at which any form of life (including bacterial or other spores) occurs normally, but excludes such artefacts as flights in the stratosphere and space.

Although intricately variable in its physical make-up of 'earth, air, sunshine, salts, and water', and eternally varying in its living inhabitants of plants, animals, microbiota, and their aggregates as components of ecosystems, The Biosphere has, from early in its evolution through thousands of millions of years, functioned as an integrated whole. But now its integrity is being jeopardized by relentless surges in the numbers and dominance of one of the millions of species on Earth, and increasingly threatened by the dangerous capabilities inherent in the unique brainpower of that species.

The species concerned is the human one, Homo sapiens, to which we all belong. Not only do we (1) live in The Biosphere and form an integral part of it, but we are (2) absolutely dependent on it as our only known life-support system, and yet (3) gravely menacing it by the ever-increasing range of our capabilities and intensity of our actions. These actions include such insidious ones as covering more and more of the world's best agricultural land with buildings and concrete, removing forests and cultivating more and more 'marginal' lands while leaving their areas open to desertification or erosion, and altering the atmosphere's content of such gases as carbon dioxide and ozone. Yet we are utterly dependent on the health of The Biosphere which we are thus threatening-most drastically of all by the present horrendous build-up of nuclear weapons, which are widely stated to be sufficient several times over to devastate our current civilizations and conceivably even to end all life on Earth.

The basic hope for remedy of this unprecedented dilemma of fear for our means of survival is, surely, world-wide education concerning The Biosphere, our part in and dependence on it, and what needs to be done throughout the world - by local actions but global strategy - to relieve the threats which we are imposing on it and hence on ourselves. To such ends three concerned environmentalists, writing from as many different continents, jointly proposed some years ago an 'International Year of the Biosphere', which was soon upgraded to 'The World Decade of The Biosphere', and subsequently altered to the above title of the 'World Campaign for The Biosphere' as explained on page 92 of this issue. For this basically educational device, as declared and further indicated on the following pages, there is now an urgent and widespread call, with proffered practical support which we submit and supplicate should be led by the United Nations-primarily through their Environmental Programme (UNEP) acting as coordinator and continuing activator.

We accordingly commend for due fostering in currently enlightened circles — and ultimately in the rest of the world as it becomes enlightened - this much-needed Campaign. Although major bodies interested may well act with more wisdom and precision, it seems to us that this paramount cause might best be promoted in the manner outlined in the Editorial (pp. 7-8) in our latest issue and further stressed in the early papers of the present one.

We could then visualize a world-wide uprising in support of the Environmental Movement, based on the theme of 'This is Our Biosphere to cherish and maintain', and stimulating concerted action to 'ensure for Man and Nature a lastingly robust future'. Such a prospect of belonging to, and hence feeling for, a common cause, could engender fervent hope and concomitant action throughout the world.

N.P. 